\title{
Unmasking Christie
}

\author{
Jessica Milner Davis \\ University of Sydney \\ jessmd@bigpond.net.au
}

I first met Christie Davies in Cardiff in July 1976. The occasion was the First International Conference on Humour and Laughter, convened under the auspices of the Welsh Branch of the British Psychological Society. Neither Christie nor I were psychologists, but that did not matter, as the co-convenors, Hugh C. Foot and Anthony J. Chapman (both then at UWIST Cardiff $^{1}$ ), had been at pains to point out that their Call for Proposals was very open. I was then living in the Bay Area of San Francisco and teaching at Stanford University. ${ }^{2}$ This had given me the inspiring experience of teaming up with William F. Fry Jr. (Psychiatry, Stanford), Arthur Asa Berger (Social Sciences, San Francisco State University), Wallace Chafe (Linguistics, University of California Santa Barbara) and others to set up the Bay Area Humor Association (BAHA). An informal and rewarding group, three members of it travelled to Cardiff, myself, Arthur Berger and Bill Fry. ${ }^{3}$

The conference was an eye-opening experience for me, trained as I was in literature and history of theatre. It endorsed the kind of cross-disciplinary approach that BAHA had also tentatively taken and it set a pattern of openness to new ideas about studying humour and laughter that - to its great credit - the ISHS has steadfastly pursued ever since. As many readers will know, the proceedings were published in It's a funny thing, humour: International conference on humour and laughter (1977). Christie Davies' contribution, "The changing stereotypes of the Welsh in English jokes", appears on pages 311-314. Although it is quite short, has only one note and three references, one can clearly see in it the shape of things to come. There is the typical tabulation of laboriously compiled statistics, an immensely wide reading reaching back into Early Modern times, and a deep insight, reflecting both high intellect and evident enjoyment of unusual, even slightly taboo materials. It is a great read and deserves republication. And it was, I recall, a delightful delivery by someone who was obviously proud of his Welsh origins, culminating in the playful but also quite serious judgement that, while the Welsh undoubtedly provide the English with hours and hours of entertainment, they themselves do not have a sense of humour but rather a sense of fun. When I got to know Christie better, this seemed exquisitely apposite.

There was only one draw-back when we next met. I was introduced to this figure of a scarecrow, with tousled hair, a fishing jacket with bulging pockets, trousers whose creases had long expired, and a very welcoming twinkle in his eye. The last feature seemed right and familiar from Cardiff, but the man himself was at least 30 years too young. I enquired cautiously if I had heard the name correctly, Christie Davies. Yes, was the answer. I asked if he was indeed the author of the paper on the Welsh sense of humour that I had enjoyed in 
Cardiff-yes, he was. And then, he sprang the joke on this unsuspecting Aussie target: the Christie Davies who had read the paper in Wales had been his father, G. Christie H. Davies, not J. Christie H. Davies, the author. ${ }^{4}$

I never did find out why Christie was not at the Conference himself; possibly he was immured in the depths of some dusty archives. Certainly, his contribution to the program came in late (it was not part of the original printed version). But he had recognised the significance of the event and sent his best thoughts on the matter. The conference truly did light the spark that led to the establishment (much later on) of the International Society for Humor Studies (ISHS) and to the foundation of HUMOR: International Journal of Humor Research and much else.

What I did find out was that connections between Christie and myself extended well beyond Cardiff. To begin with, we both had grandfathers who were born in Barnsley, a benighted Yorkshire mill town that long ago earned itself a reputation for lack of education and finesse. Was wondering about this (real but surely unfair) characterisation perhaps something that inspired Christie to his life-long study of - possibly addiction to-jokes and stereotypes? He certainly took great delight in inserting a good Barnsley story into his contribution to a book I am currently preparing on judges and humour and in pointing out in his meticulous way that the setting is vital to the joke. ${ }^{5}$ This piece is worth quoting here, both for its own sake and as an example of how Christie went about his art most scientifically, collecting, dissecting and classifying those ordinarily overlooked common cultural artefacts, jokes and anecdotes. To him, the distinction between the two was important and something that he was actively researching particularly in the last couple of years.

Widely collected and retold (especially in legal circles), this particular anecdote concerns the legendary British lawyer, F. E. Smith (1872-1930). From the context, it can be inferred that the tale relates to the case of a miner from Barnsley who had applied for compensation for an industrial injury but who had only done so after the prescribed statutory limit had expired. Set in the courtroom, the anecdote has the appearance of reality and runs thus: ${ }^{6}$

Judge: Your client is, I take it, Mr. Smith, aware of the principle of vigilantes et non dormientes inveniunt legem?

F. E. Smith: I do assure you, M'Lud, in Barnsley they talk of little else.

Christie comments: "The legal Latin means roughly, that the law will assist only those who are vigilant, not those who are careless of their rights; in this case, that you cannot sue after the time limit has expired. The subtle humour lies in the fact that the ordinary person who knows neither legal nor classical Latin will not have a clue what it means and that the judge ought to know this. F. E. Smith is thus making fun of the judge's ignorance of others' ignorance. The place chosen is important to the situation: Barnsley, a rough mining town in South Yorkshire, has little access to high culture and learning. One might say that Latin is all Greek to its inhabitants. Barnsley is not just a mining town, it is literally the pits." This last is a typical Christie joke on pits and mining, his reaction to an irresistible opportunity; but he goes on very seriously to question what really interests him about this text and its provenance: "But the question arises, is this really an anecdote, or is it a joke with Barnsley chosen as the perfect setting? And has F. E. Smith been put into the text simply because of his reputation for making wisecracks of this kind? In other words, is this a true anecdote [something that really happened or that claims to have happened], or is it on the way to becoming something else, perhaps a standard joke?" I do not intend to spoil his labours by signalling here his careful conclusion: I hope you will read it when the full study is published next year.

Our grandfathers both left Barnsley for better education and more opportunities for themselves and their families, although they headed in very different directions. But Christie and I found we shared other affiliations as well. Of course, there was our common dedication 
to taking humour seriously as a matter for academic investigation. For me, that had begun very early with my doctoral studies on comedy in Australia in the mid-1960s, and it continued at the University of Bristol and in the USA. I was trying to work out why farce, the most lowly and physical form of comedy, should also be, a) so demanding as a theatrical performance genre and b) so non-culpable, despite its aggressive taboo violations. Christie went to Cambridge as Wrenbury Scholar at Emmanuel College and took his MA and PhD in political economy, not comedy. Nevertheless, he did very much enjoy his time in the famous Cambridge Footlights theatre club. He told me once that he had successfully matched wits (and perhaps other things) there with Germaine Greer, the most fearsome of our Australian-born feminists and author of The Female Eunuch (1970). Her side of the story remains unknown. But certainly, they performed alongside each other in the 1965 Footlights Annual Review, My Girl Herbert (see Figure 1.1 below). ${ }^{7}$

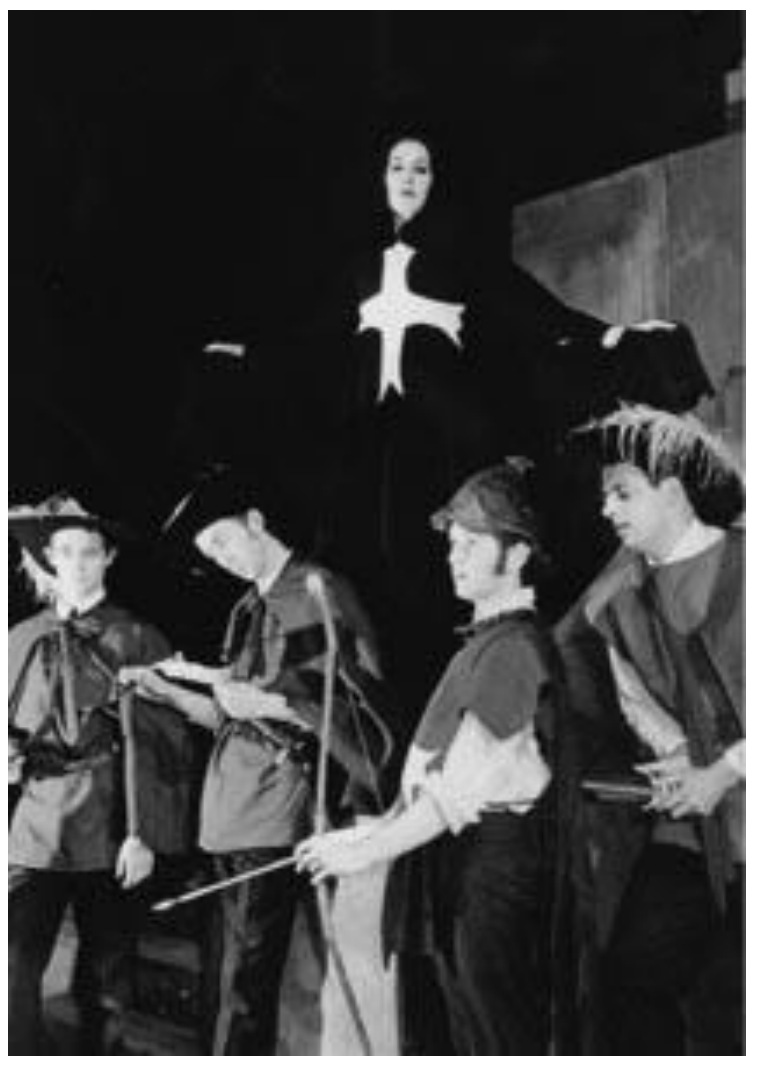

Figure 1. My Girl Herbert, the Cambridge Footlights Actors Review 1965, with Germaine Greer presiding over Eric Idle and others (perhaps including Christie?)

Perhaps it was this encounter that suggested a future course of action to Christie. Completing his doctorate, he decided to take an academic appointment in Australia. Having acquired not only his degrees but also (to Australian ears) a fairly upper-class English way of speaking (what Australians call "a pommie accent"), he set out to teach English language and literature at the University of Adelaide in South Australia. His assigned class was certainly not literary students: it was made up of engineering students doing their despised compulsory subject in "the humanities". I too have taught such classes, ${ }^{8}$ and I can well imagine the rowdy ungovernable behaviour that greeted this pommie just arrived from England. Australians take a special delight in "taking the piss/taking the mickey" from their former colonial masters and young Christie would have been regarded as fair game. And so it was that here in Adelaide the famous "Davies Joke Data-base" began. It happened thus: unable to hear himself speak in his 
classroom for whoops, catcalls and other distractions, Christie offered a desperate bargain. If the class would settle down and listen quietly (after all they did have an exam to sit at yearend), he promised to finish five minutes before time and to allow them then to share the rudest jokes they could think of. A deal was done and the rest was history.

In fact, Christie maintained a special affinity for Australia and its permissive and uncontrollable joking culture. He agreed with Philip Adams and Patrice Newell in their multivolume collections of Australian jokes for Penguin, when they recorded in amazement how many offensive (and racist) jokes they managed to collect and print without any outraged objections coming their way. They commented that Australians must "fear the 'other', what we deem to be foreign or alien, and so tell savage, uncivilised jokes about Aborigines, Jews, migrants...Jokes that are bigoted, blasphemous or phobic outnumber all other categories [in our book]" (1996: 8). As the British writer, Ken Hunt, ironically put it, "[t]o live in Australia, Aussies have to have a sense of humour. It's a cheap form of entertainment and helps pass the time" (1993: 42). As an Australian made, not born, I also learned this the hard way; but unlike Christie, that happened when I was a child not an adult. Australian culture in fact deploys humour quite openly as a weapon to identify those who are truly "at home", both in the land and the society. To me, it is these conventions of "jok(e)-ing" rather than the nature of the jokes that indicate "Australian-ness": that is, it is how Australians use humour, rather than the nature of the humour used, that characterises "Australian humour". Visitors and new arrivals can and do find themselves under humorous attack from the moment they set foot in the country and often need a degree of explanation and mediation to survive the experience.

Whatever its origins, ${ }^{9}$ this Australian custom of "taking the mickey" (baiting others, particularly the most obviously "other", with joking, teasing and insult) enjoys such broad social permission that objecting in any particular instance is not only ineffective, it is counterproductive. Hidden cultural rules decree that when its victim either rejects the baiting or "doesn't get it", by definition the mickey has been taken. Thus, the only effective response is to accept that the mickey has indeed been taken, appreciate the skill of it and to reply in kind. Most Australians believe that taking the mickey is effectively their own national civil liberty. Most new-comers experience this with discomfort, but Christie took to the Australian practice like a duck to water. Perhaps as a Welshman, he resonated with the retaliatory element of this sense of fun.

In 2010, he came to deliver a seminar for the members of the Australasian Humour Studies Network that I had founded in 1997, following the success of that year's ISHS Conference held in Sydney. It has grown and prospered and is now hosted by the University of Sydney's Department of English. Settled comfortably into the wood-panelled surroundings of what passes for our antipodean Senior Common Room, Christie took a special pleasure in scandalising the Australian literature scholars who had ventured to join us by outlining his findings on Australia's contributions to ethnic and other put-down jokes. For those who pin their careers to Australia being an interesting pioneer in the world literary stakes, it was a sobering experience to hear that in fact our truly unique contribution to international culture is our ghastly collection of vomit and dirt jokes. ${ }^{10}$ Were the ghosts of those far-off engineering students laughing with Christie in the carved corners of the wainscoting? It was certainly payback time. But it was also an important truth. All cultures are the better for knowing the truth about themselves and facts must be faced. 


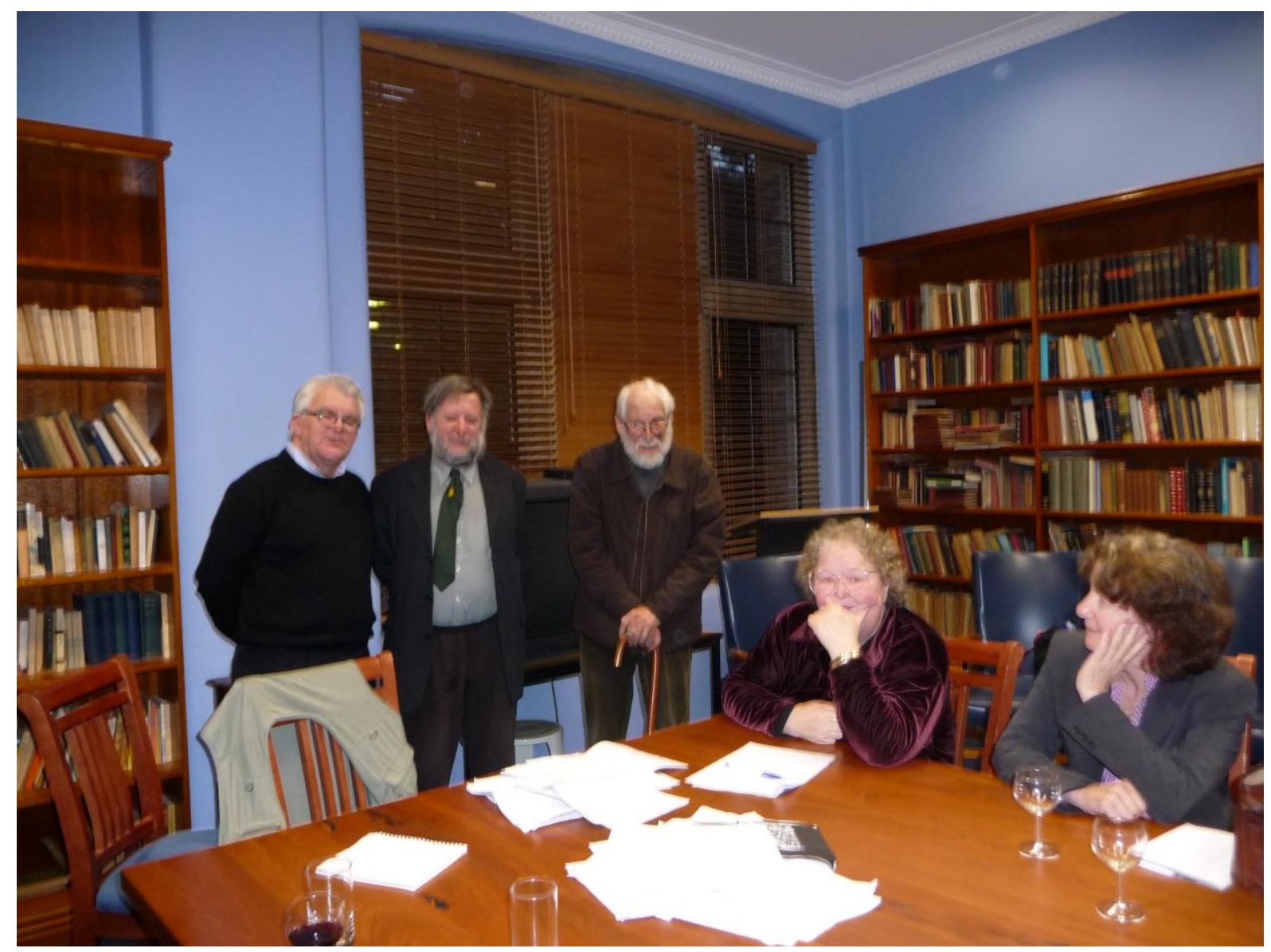

Figure 2. Christie at home in the Antipodes, after delivering his seminar on "How and why joke cycles change as they move between countries, including Australia", 2 July 2010; The

Rogers Room, Department of English, University of Sydney. L-R (standing): Peter

Kirkpatrick, Christie Davies, Douglas Muecke; (seated): Marguerite Wells, Lyn Ashcroft

Playful aggression is a human reality, however much political correctness might tell us it should not be. Adopting it as a field of research is not popular in academic circles unless accompanied by clear signals of moral condemnation. Christie argued that this was unjustified and adduced the facts to demonstrate his case. He accepted the stigma attaching to his chosen topic as a badge of honour, and here again we found common ground. I adopted farce as I have said in my student days and it too suffers from an unjustified stigma among theatre and literary critics. I think aggressively physical comedy such as farce deserves to be studied without pre-judgment and I see much value - as Christie did - in observing how different cultures develop rules to safely contain these kinds of humour. Studying the way in which they are framed and structured and seeing how such humour varies according to mediation by human agency such as an individual performer or narrator allows us to become aware of their complexity. Their demanding rules of internal structure and patterning deserve as much examination as do more benign and gentle forms such as romantic comedies, linguistic puns and word-plays. Aspects of control range from broadly cultural and class-based taste-preferences to legal and commercial restraints, as well as political resistance and overt censorship; and the evolutionary significance of playful aggression is surely unquestioned. The field of humour studies has much to learn from looking objectively at what provokes retaliation and control and also at how it 
manages to evade such restrictions and with what consequences. Prejudging the issue can never serve science well.

Christie went further in his appreciation of playful aggression: he adopted it as a kind of scholarly modus vivendi. He spent his life sticking to his guns and also in outgunning the opposition with facts. Naturally, this was confronting for many-even in the world of humour scholarship. One came to rely on Christie's jesting injections in meetings and on his arresting insights in response to many a book and paper. It was his way of challenging what he saw as complacency and shallowness of thought. Nevertheless, when one approached him personally, the impression of Dionysiac disorder was immediately dispelled (apart from anything else, he never drank alcohol). Christie was gentleness personified. His overwhelming concern waslike all truly great scholars - for the next generation of emerging scholars and how best to help them. It was only typical that when he came to speak at Sydney University, he also freely offered individual counselling sessions to five lucky research students (all of whom have now successfully completed). Above all, Christie was a superb mentor and colleague.

Having swum against the stream in his redbrick British university for many years (18 of them as a full professor), honours finally came his way. He was created Emeritus Professor of Sociology, he served as President of the ISHS (2007-2009) and received its Life-time Achievement Award as well as an honorary doctorate (from Duneara de Jos University). Christie valued such honours but he wore them lightly: he had never aspired to be a pillar of the establishment. How could he, when he revelled in mentioning the unmentionable, insisting on facts and calling a spade a spade? Whatever else he was, this Emeritus Professor was never the dreary stereotype of droning scholar captured by the legal cartoonist in Figure 3 below. ${ }^{11}$ Christie wore his erudition lightly: he was never boring, he was eminently kind and patient with his interlocutors, he was mesmerising to listen to, whether in conversation or a formal presentation and his writings will undoubtedly stand the test of time. Welsh and proud of it, he was nevertheless the very model of an eccentric but internationally acclaimed English scholar. And part of him, converted long ago by those rowdy Engineering students at University of Adelaide, was Australian.

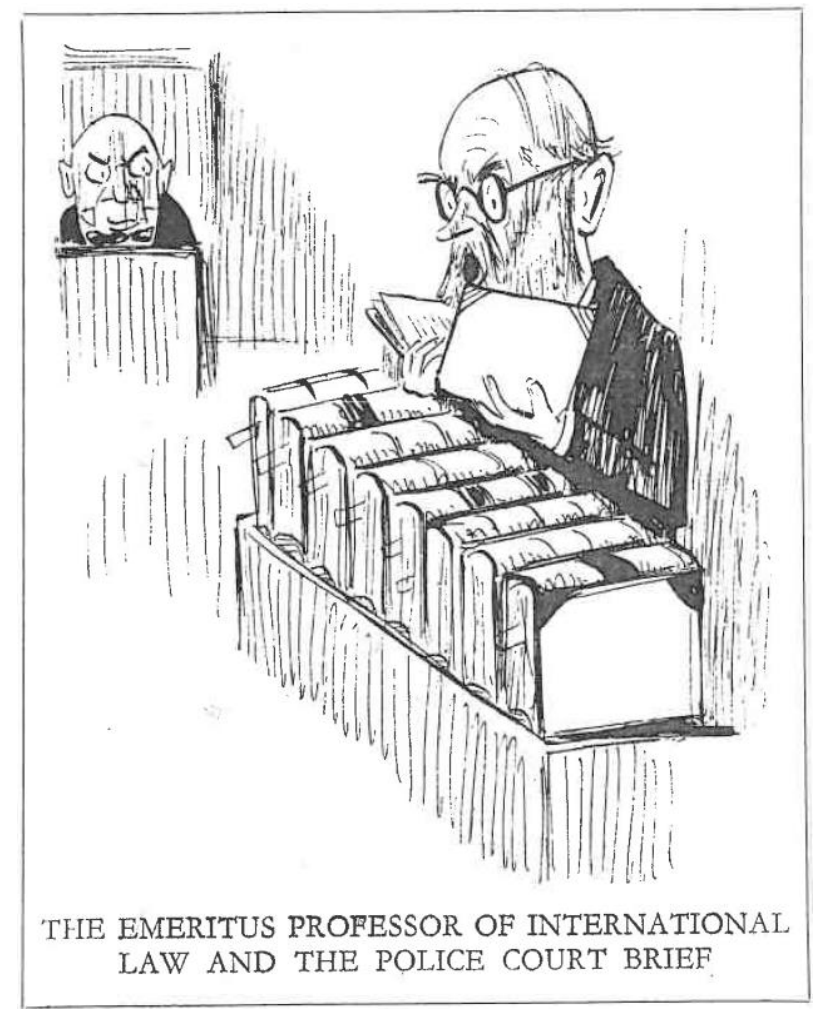


Figure 3. "The emeritus professor of international law and the policy court brief". Cartoon by “O”, originally published in Punch Magazine, 1853, reproduced in "O” [Theo Mathew], Further forensic fables by O. 1928. London: Butterworths (from a copy owned by the author)

\section{Notes}

${ }^{1}$ University of Wales Institute of Science and Technology, part of the University of Wales / Prifysgol Cymru.

${ }^{2}$ I have to state here that I was teaching as a visiting scholar, otherwise even after all these years, the US Internal Revenue Service will be after me, asking how I could validly teach (which entailed remuneration by the University) when I did not hold a working visa. The short answer is that Stanford paid me and I donated the money straight back to Stanford. Unfortunately, this meant that my teaching failed to show up in the normal way on my CV. Such are the perils of trying to pursue an international career. But I enjoyed it, nevertheless.

${ }^{3}$ One of Fry's two contributions, "The appeasement function of mirthful laughter", appears at pp. 23-26; the second, "The world of comedy: Introduction to the Symposium", at pp. 379-84. Berger's abstract, "Humour as a system of communication", is at p. 403; my own, "A structural approach to humour in farce", at pp. 391-4. Bill Fry passed away in 2014, after being honoured by the ISHS with a Lifetime Achievement Award for his many publications and research achievements. Arthur and I soldier on.

${ }^{4}$ Look carefully at Chapman and Foot (1977), pp. 505-7, which lists the Contributors to the Conference (note, Contributors, not Attendees), and you will find both the Davies listed. I never thought to ask Christie whether he negotiated this malleable heading with the editors, but it would not surprise if he had.

${ }^{5}$ It gave Christie great pleasure to prepare this contribution to a study of judges, judging and humour. He himself has published on the law and acted by invitation as an amicus curiae at the US Supreme Court, as well as providing evidence for the British Law Commission's report, "Consent in the Criminal Law" (Report No. 139, 1995). Married to Janneta Davies, a leading solicitor for the defense in criminal trials in England and Wales and a former Crown Prosecutor, he felt satisfaction in connecting their different bodies of knowledge in this forthcoming chapter.

${ }^{6}$ Sources: Dick Collins (1998) 'Historia urinalis. Re-reading Les Trois Meschines', p. 397; Iqbal Jafar (2012) 'Lawful Humour'.

${ }^{7}$ The company comprised: Eric Idle, Sheila Buhr, John Cameron, Christie Davies, John Grillo, Germaine Greer, Robin Nelson, Mervyn Riches and Matt Walters. Script writers included Eric Idle and Clive James (later an Australian writer and commentator).

${ }^{8}$ In the humanities program at the University of New South Wales in Sydney in the 1960s and the 1980s. I also have a brother and many friends who are engineers and applied scientists.

${ }^{9}$ On this complex topic, see: J. Milner Davis (2007) “Taking the mickey': A brave Australian tradition'. I argue for both a Cockney and an Irish-Celtic inheritance, while pointing to resonance with an Indigenous tradition of teasing and mockery. On mickey-taking as an acculturating practice, see J. Milner Davis (2009) 'A Aussie' humour and laughter: Joking as an acculturating ritual.'

${ }^{10}$ See Davies (2002) The Mirth of Nations, pp. 92-102; Davies (1997) 'The progress of Australian humour in Britain', pp. 21-5. 
11 The work of "O", or Theo Mathew (1866-1939), lawyer and wit, forms part of the corpus of British legal humour canvassed by Christie in his forthcoming study, "Judges and humour in Britain: From anecdotes to jokes", in Judges, judging and humour, eds. Jessica Milner Davis and Sharyn Roach Anleu (Palgrave Macmillan).

\section{References}

Adams, P. \& Newell, P. (eds.) (1996). The Penguin Book of More Australian Jokes. Ringwood VIC: Penguin Books Australia.

Chapman, A.J. \& Foot, H.C. (eds.) (1977). It's a Funny Thing, Humour: International Conference on Humour and Laughter. Oxford: Pergamon Press.

Collins, D. (1998). 'Historia urinalis. Re-reading Les Trois Meschines'. French Studies 52 (4): 397-408.

Davies, C. (2002). The Mirth of Nations. Piscataway NJ: Transaction Publishers.

Davies, C. (1977). 'The progress of Australian humour in Britain', in Matte, G. \& Milner Davis, J. (eds.), Readings from International Conference on Humour. Special Issue of Australian Journal of Comedy 3 (1): 15-32.

Davis, J. M. (2007). 'Taking the mickey': A brave Australian tradition', The Fine Print (ezine), 4: 20-27 (website inoperative, September 2017; text posted at: http://sydney.academia.edu/JessicaMilnerDavis).

Davis, J. M. (2009). 'Aussie' humour and laughter: Joking as an acculturating ritual', in Kirkpatrick, P. \& de Groen, F. (eds.), Serious Frolic: Essays on Australian Humour, St Lucia QLD: University of Queensland Press, pp. 31-47.

Hunt, K. (1993). The Xenophobe's Guide to the Aussie. Partridge Green, West Sussex: Ravette Books.

Jafar, I. (2012). 'Lawful humour', The International News, 11 October 2012. At: http://www.thenews.com.pk/Todays-News-9-136956-Lawful-humour (accessed 3 November 2015). 